

(CASE REPORT)

\title{
The effect of leadership on job satisfaction and employee performance (Case study: Geo space Intimatika Ltd. in Jakarta)
}

\author{
Idrus ${ }^{1, *}$ and Muhammad Yusuf 2 \\ ${ }^{1}$ Department of Development Economics, College of Economics, YAPTI Jeneponto, Jalan M Ali Gassing No 1, Jeneponto, \\ South Sulawesi, 92315, Indonesia. \\ 2 Department of Fisheries Agrobusiness, Cokroaminoto University Makassar, Jl.Perintis Kemerdekaan Km 11, Tamalanrea \\ Makassar, South Sulawesi, 90245 Indonesia.
}

International Journal of Science and Research Archive, 2021, 03(02), 128-133

Publication history: Received on 20 August 2021; revised on 27 September 2021; accepted on 29 September 2021

Article DOI: https://doi.org/10.30574/ijsra.2021.3.2.0143

\begin{abstract}
Leadership is one of the factors that have an important role in achieving the company's vision and mission. The purpose of the research is to find out the influence of leadership on job satisfaction and employee performance at Geo Space Intimatika Ltd. (GSI). There were three hypotheses tested: 1) The effect of leadership on job satisfaction, 2) The influence of leadership on employee performance, and 3) The effect of job satisfaction on employee performance. The research was conducted at Geo Space Intimatika Ltd. in Jakarta. Sampling is done on a census basis (saturated samples). The data analysis method used is SEM-PLS analysis, with the help of smart PLS software. The results of statistical test analysis obtained that leadership variables have a real (significant) effect on job satisfaction and employee performance at Geo Space Intimatika Ltd. In addition, job satisfaction variables also affect employee performance. Thus it can be concluded that leadership factors greatly affect the company's performance.
\end{abstract}

Keywords: Leadership; Performance; Employees; Influence

\section{Introduction}

According to [1] leadership is the ability to influence a group to achieve a vision or set of specific goals. In a simpler sense, leaders must be able to set directions and goals by developing a vision of the future to be achieved, and then communicating that vision. If the leadership style applied in accordance with the situation faced in the company, it will make the work atmosphere conducive, and will ultimately provide high motivation for employees to give their best performance in doing the work. The role of a leader not only shows the direction of a company in achieving its vision and mission, but the role of a leader must be able to take a role in the face of a change that occurs continuously and uncertainly [2].

From the results of observations on the ground found that differences in employee performance are also influenced by leadership styles, such as; If the leader often organizes and directs, supervises and hold employees accountable, it provides a different performance impact when compared to leadership styles that rarely provide motivation or lack of supervision. The impact of leadership on employee performance is huge. According to [3] that if the leadership is able to implement the right leadership, then employees will have job satisfaction and can improve employee performance. Research that reinforces the theory that there is a positive relationship between leadership and employee performance, among others; $[4,5]$ where the results of his research prove that leadership has a positive and significant effect on employee performance.

\footnotetext{
${ }^{*}$ Corresponding author: Idrus

Departement of Development Economics, College of Economics, YAPTI Jeneponto, Jalan M Ali Gassing No 1, Jeneponto, South Sulawesi, 92315, Indonesia.

Copyright (C) 2021 Author(s) retain the copyright of this article. This article is published under the terms of the Creative Commons Attribution Liscense 4.0.
} 
According to $[6,7,8]$ that performance can be interpreted as a result of work achieved by a person in carrying out tasks assigned to him based on skills, experience, and earnestness. There is an influence between job satisfaction and employee performance as stated by [9] that job satisfaction has a significant positive effect on employee performance. This statement is reinforced from the results of [10] and [11] research that proves that there is a meaningful relationship between job satisfaction and employee performance. Against the background of theoretical studies, the results of previous research and empirical facts, research conducted the relationship between leadership variables to job satisfaction and performance, and between job satisfaction to employee performance.

Geo Space Intimatika Ltd. (GSI) is one of the national companies engaged in various fields such as; mapping consultants, procurement of goods and services and trading. GSI Ltd. is headquartered in Jakarta and established since 2000. Currently GSI Ltd. has 32 employees and has developed a business to areas in Indonesia. Therefore, to find out how the role / influence of leadership on job satisfaction and employee performance becomes very important to do.

\section{Material and methods}

\subsection{Time and Location of Research}

The research was conducted at Geo Space Intimatika Ltd. in Jakarta on the grounds that its success survived in the midst of very intense competition, and developed giving birth to other business units in various fields. The population in this study is all employees of Geo Space Intimatika Ltd. numbering 32 persons. Sampling technique using saturated samples (census).

\subsection{Types and Sources of Data}

The type of data in this study is primary data obtained from respondents' answers to a number of questions and statements in questionnaires related to research variable indicators. According to [12] primary data is data obtained directly from the research subject either in the form of data or information using established guidelines. Research variables consist of exogenous variables is leadership $\left(\mathrm{X}_{1}\right)$, and endogenous variables i.e.; job satisfaction ( $\left.\mathrm{Y}_{1}\right)$, and employee performance ( $\left.\mathrm{Y}_{2}\right)$.

- Leadership $\left(\mathrm{X}_{1}\right)$ is the ability to influence individuals or groups in carrying out activities to achieve organizational goals $[3,13,14]$.

- Job Satisfaction ( $\mathrm{Y}_{1}$ ) is an emotionally pleasing or unpleasant attitude of employees towards their work compared to the return of services received in accordance with expectations $[7,15,16]$.

- Employee Performance $\left(\mathrm{Y}_{2}\right)$ is the achievement produced by employees in carrying out the tasks charged based on proficiency, experience and earnestness and time [17].

\subsection{Data analysis}

The data analysis method used to analyze the influence of leadership variables on job satisfaction and employee performance is Structural Equation Modeling (SEM) with a variance based or component based approach through Partial Least Square [18]. PLS (Partial Least Square) is a multivariate statistical technique that can be used to handle many response variables as well as explanatory variables at once [19]. Furthermore, according to [20] that PLS analysis is a good alternative to multiple regression analysis methods and major component regression, because this method is more robust. SEM-PLS (Structural Equation Modeling-Partial Least Squares) in this study was used to test models, by providing a systematic evaluation of SEM-PLS results as suggested by [21]. The analysis is intended to answer the hypothesis built as follows:

- There is a leadership influence on employee job satisfaction at Geo Space Intimatika Ltd.

- There is a leadership influence on employee performance at Geo Space Intimatika Ltd.

- There is an effect of job satisfaction on employee performance at Geo Space Intimatika Ltd.

\section{Results and discussion}

\subsection{Evaluation of Measurement Model (Outer Model)}

Evaluation of the measurement model consists of; validity test and reliability test. Validity tests include; a) Convergent validity is estimated based on factor loading values, and AVE values, and b) Discriminat validity is estimated based on 
Fornell-Larcker Criterion/HTMT values and cross loading values. While the reliability test consists of; a) Composite reliability, and b) Cronbach's alpha.

- Convergent validity It is a measure to know how well a test or survey is being conducted. Convergent validity is defined as a measure based on correlations between different items on the same test. It is intended to find out if multiple items used to measure the same construct/latent can produce a similar score. The first evaluation conducted on the results of SmartPLS analysis is the evaluation of the measurement model (measurement model) by estimating the value of loading factors. The loading factor value is the value produced by each indicator to measure its latent variable. The value is illustrated from the outer loading value, with the indicator a value of greater significance than $>0.7$. Here is a breakdown of the outer loading value of the indicator.

Table 1 Outer Loading Value

\begin{tabular}{|l|l|c|}
\hline \multicolumn{1}{|c|}{ Variable } & \multicolumn{1}{|c|}{ Indicators (Questions/Statements) } & Outer Loadings \\
\hline \multirow{4}{*}{ Leadership } & Ability to communicate/relationship & 0.801 \\
\cline { 2 - 3 } & Ability to delegate/grant authority & 0.716 \\
\cline { 2 - 3 } & Ability to solve problems/ find solutions & 0.841 \\
\cline { 2 - 3 } & Surveillance capabilities & 0.821 \\
\hline \multirow{4}{*}{ Sab } & Work according to expertise & 0.825 \\
\cline { 2 - 3 } & Satisfaction with salary and reward & 0.707 \\
\cline { 2 - 3 } & Satisfaction with the harmony of work & 0.921 \\
\cline { 2 - 3 } & Satisfaction with job responsibilities & 0.880 \\
\hline \multirow{4}{*}{$\begin{array}{l}\text { Employee } \\
\text { Performance }\end{array}$} & The results of the work reached the target & 0.762 \\
\cline { 2 - 3 } & Working on time & 0.865 \\
\cline { 2 - 3 } & Working well together as a team & 0.790 \\
\cline { 2 - 3 } & Completing the task very well & 0.850 \\
\hline
\end{tabular}

- Evaluation of the indicator significance assessment is good enough to reflection its latent variables are estimated based on the value of outer loadings with significance values above $>0.7$. Based on these values, it is concluded that overall the indicator is significant or good enough to regulate its latent variable, where the loading factor value $<0.7$. According to [22] that individual reflective measures are expressed high when correlated by more than $>0.7$.

- In addition to validating the loading factor value, in PLS there is also a validity test of the AVE (Average Variance Extracted) value. AVE value is the value that each latent variable / construct has or measured. The AVE assessment indicator is an AVE value $>0.5$ then it is declared valid, and if it is less $(<0.5)$ it is declared invalid. Based on the results of the analysis, the AVE value is obtained as follows:

- Based on the AVE value, it is obtained that the entire construct / latent is well illustrated, where the value of $\mathrm{AVE}>0.5$ or categorized as valid. Thus, it can be concluded that the model is sufficient valid.

Table 2 AVE value

\begin{tabular}{|l|c|c|c|c|}
\hline & Cronbach's Alpha & rho_A & $\begin{array}{l}\text { Composite } \\
\text { Reliability }\end{array}$ & $\begin{array}{l}\text { Average Variance } \\
\text { Extracted (AVE) }\end{array}$ \\
\hline Leadership & 0.795 & 0.836 & 0.877 & 0.705 \\
\hline Job Satisfaction & 0.931 & 0.953 & 0.950 & 0.826 \\
\hline Employee Performance & 0.766 & 0.787 & 0.863 & 0.679 \\
\hline
\end{tabular}




\subsection{Evaluation of Structural Models (Inner Model)}

Structural model evaluation or also known as inner model evaluation is an evaluation conducted to find out whether the proposed model in the path diagram (theoretical model) is suitable (fit) or not with data. One indicator that can be used to assess the specificity of the model is the VIF value.

- Variance Inflation Factor (VIF) values are intended to test collinearity. The VIF value indicates that there is multi collinearity in the resulting model. Indications of the occurrence of multi-collinearity can be known from the value of VIF $>10$. If the value of VIF $>10$ then the model indicates the presence of collinearity between constructs [21]. Here is the result of the VIF value analysis.

Table 3 Nilai VIF

\begin{tabular}{|c|c|l|}
\hline Indicators & Variance Inflation Factor (VIF) & Criterion \\
\hline Pim1 & 1.738 & Free of collinearity \\
\hline Pim2 & 9.019 & Free of collinearity \\
\hline Pim3 & 1.700 & Free of collinearity \\
\hline Pim4 & 6.360 & Free of collinearity \\
\hline Pua1 & 8.968 & Free of collinearity \\
\hline Pua2 & 1.485 & Free of collinearity \\
\hline Pua3 & 2.023 & Free of collinearity \\
\hline Pua4 & 2.395 & Free of collinearity \\
\hline Kin1 & 6.467 & Free of collinearity \\
\hline Kin2 & 1.607 & Free of collinearity \\
\hline Kin3 & 1.598 & Free of collinearity \\
\hline Kin4 & 1.570 & Free of collinearity \\
\hline
\end{tabular}

- The results of the analysis as in the table above show that overall the indicators used as presumptions in the model are quite good and free from the symptoms of multi-collinearity, namely with a value of VIF $<10.0$ which means in the resulting model there are no symptoms of multi-collinearity. Thus the model's predictive ability becomes quite good [23].

\subsection{Path Coefficient}

Path coefficient is a value that shows the direction of the relationship between variables, where the value is spread between -1 (negative) to +1 (positive). Here are the results of the value analysis path coefficient.

Table 4 Value of Path Coefficient

\begin{tabular}{|l|c|}
\hline Variable & Value of Path Coefficient \\
\hline Leadership $\rightarrow$ Job Satisfaction & 0.490 \\
\hline Leadership $\rightarrow$ Employee Performance & 0.381 \\
\hline Job Satisfaction $\rightarrow$ Employee Performance & 0.352 \\
\hline
\end{tabular}

The results of the analysis showed the overall path coefficient value is positive which means the relationship / influence formed is a positive relationship. Results as in the table above show that the relationship between variables is unidirectional. In other words, that if a variable increases, then other variables also increase. 


\subsection{T-Statistics}

The t-test is the value for describing the significance of the model. The t-test is performed with a 95\% confidence level (sign. 0.05) with a 2-way (two tailed) method. The t-test assessment indicator (t-statistic) is that the value must be above $>1.96$ then stated significant or by looking at the value $p$-Value must be smaller than the alpha $<0.05$. Here are the results of the t-test analysis (t-statistics).

Table 5 T-Statistical Value

\begin{tabular}{|l|c|c|c|c|c|}
\hline & $\begin{array}{l}\text { Original } \\
\text { Sample } \\
\text { (0) }\end{array}$ & $\begin{array}{l}\text { Sample } \\
\text { Mean } \\
\text { (M) }\end{array}$ & $\begin{array}{l}\text { Standard } \\
\text { Deviation } \\
\text { (STDEV) }\end{array}$ & $\begin{array}{l}\text { T Statistics } \\
(\mid \mathbf{O} / \text { STDEV } \mid \text { ) }\end{array}$ & P Values \\
\hline Leadership $\rightarrow$ Job Satisfaction & 0.250 & 0.258 & 0.051 & 2.725 & 0.007 \\
\hline Leadership $\rightarrow$ Employee Performance & 0.390 & 0.392 & 0.052 & 6.892 & 0.000 \\
\hline $\begin{array}{l}\text { Job Satisfaction } \rightarrow \text { Employee } \\
\text { Performance }\end{array}$ & 0.280 & 0.275 & 0.067 & 3.701 & 0.018 \\
\hline
\end{tabular}

- $\quad$ The results of the analysis found that there are all influential variables in the model where the P-value Smaller than $<0,05$ The T-statistics value is greater than value T-table $(>1,960)$. For this reason, it can be concluded that leadership variables are directly related to job satisfaction and employee performance.

\section{Conclusion}

Based on the results of statistical test analysis, it was obtained that leadership variables have a real (significant) effect on job satisfaction and employee performance at Geo Space Intimatika Ltd. In addition, job satisfaction variables also affect employee performance. Thus it can be concluded that leadership factors greatly affect the company's performance.

\section{Compliance with ethical standards}

\section{Acknowledgments}

Thank you for the collaboration between the two universities, namely; Economics College of YAPTI Jeneponto and Cokroaminoto University Makassar. Thank you to the chairman of Geo Space Intimatika Ltd. in Jakarta and staff for cooperation during the research took place.

\section{Disclosure of conflict of interest}

In principle we do not have a conflict of interest, considering our role and field of study which is different.

\section{Statement of informed consent}

All information and statements obtained from respondents (informants) are for research purposes and will be maintained.

\section{References}

[1] Robbins Stephen P., Timothy A Judge. Organizational Behavior. 12th Edition. Book-1. Translation: Diana Angelica, Ria Cahyani dan Abdul Rosyid. Jakarta: Salemba Empat. 2008.

[2] Mangkunegara, Anwar Prabu. Evaluation of Human Resource Performance. Bandung: PT. Reflika Aditama. 2006.

[3] Yukl Wexley K.N. Organizational Behavior and Personnel Psychology. Jakarta: Rineka Cipta. 2011.

[4] Nurjanah. Influence of leadership style and organizational culture on the organization's commitment to improving employee performance. Thesis. UNDIP. Semarang. 2008. 
[5] Salamala Elon. Influence of Leadership Style Factors on The Work Performance of Village Unit Cooperative Employees (KUD). Executive Journal. 2007; 4(3): 538-545.

[6] Bernardin H John, Joyce EA Russel. (2001). Human Resource Management. Occupational Psychology. 2001; 63(1).

[7] Hasibuan, Malayu SP. Revised Edition of Human Resource Management. Jakarta: PT. Bumi Aksara. 2012.

[8] As'ad. Human resources science series: Industrial psychology. (Fourth edition). Yogyakarta: Publisher Liberty. 2005.

[9] Anshari, Ilham. Effect of Job Satisfaction on Employee Performance on PT. Bank Rakyat Indonesia Binjai Branch. Thesis Department of Human Resource Management Faculty of Economics, University of North Sumatra. 2007.

[10] Dizgah, Morad Rezaei, Mehrdad Goodarzvand Chegini, Roghayeh Bisokhan. Relationship between Job Satisfaction and Employee Job Performance in Guilan Public Sector. Journal of Basic and Applied Scientific Research. 2012; 2(2): 1735-1741.

[11] Ajzen I. The theory of planned behaviour: Reactions and reflections. Psychology and. Health. 2011; 26(9): 1113 1127.

[12] Yusuf M, Daris L. Analysis of Research Data; Theory \& Application in Fisheries. PT. IPB Press. Bogor. 2018.

[13] Thoha, Miftah. Organizational Behavior Basic Concepts and Their Applications. Jakarta: Raja Grafindo Persada. 2012.

[14] Gorda, I Gusti Ngurah. Human Resource Management. Revised Edition. Denpasar: Astabrata Bali in collaboration with STIE Satya Dharma. Singaraja. 2004.

[15] Luthans, Fred. Organization Behavior of 10-Edition. Terjemahan: Vivin Andhika. Yogyakarta: Andi. 2006.

[16] Rivai, Veithzal. Human Resource Management for The Second Edition of the Company. Jakarta: PT. Raja Grafindo Persada. 2010.

[17] Martoyo, Susilo. Human Resource Management, 10-Edition. First Print. Yogyakarta: BPFE. 2007.

[18] Solimun. Variable Analysis of Moderation and Mediation. Unfortunate: Study Program. Statistical FMIPA-UB. 2010.

[19] Geladi P, Kowalski BP. Partial least-squares regression: A tutorial. Analytica Chimica Acta. 1985; 185(1): 1-17.

[20] Syahrir, Danial, Eni Yulinda, Muhammad Yusuf. Application of SEM-PLS Method in Coastal and Ocean Resource Management. PT. IPB Press. Bogor. 2020.

[21] Marko Sarstedt, Christian M Ringle, Joseph F Hair. Partial Least Squares Structural Equation Modeling. Springer International Publishing AG 2017 C. Homburg et al. (eds), Handbook of Market Research. 2007.

[22] Ghozali, Imam. Aplikasi Analisis Multivariate dengan Program SPSS. (Edisi Ke 4). Semarang:Badan Penerbit Universitas Diponegoro. 2006.

[23] Sekaran U. Research Methods for Business. USA: John Wiley \& Sons, Inc. 2003. 